\title{
Dissolved and particulate reactive nitrogen in the Elbe River/NW Europe: a 2-yr N-isotope study
}

\author{
T. Schlarbaum ${ }^{1,2}$, K. Dähnke ${ }^{1,2}$, and K. Emeis ${ }^{2}$ \\ ${ }^{1}$ Helmhotz Zentrum Geesthacht, Institute of Coastal Research, Max-Planck-Str. 1, 21502 Geesthacht, Germany \\ ${ }^{2}$ IfBM, University of Hamburg, Bundesstr. 55, 20146 Hamburg, Germany
}

Received: 17 September 2010 - Published in Biogeosciences Discuss.: 19 October 2010

Revised: 28 October 2011 - Accepted: 14 November 2011 - Published: 1 December 2011

\begin{abstract}
Rivers collect and transport reactive nitrogen to coastal seas as nitrate, ammonium, dissolved organic nitrogen $(\mathrm{DON})$, or particulate nitrogen. DON is an important component of reactive nitrogen in rivers and is suspected to contribute to coastal eutrophication, but little is known about seasonality of DON loads and turnover within rivers. We measured the concentrations and the isotope ratios ${ }^{15} \mathrm{~N} /{ }^{14} \mathrm{~N}$ of combined $\mathrm{DON}+\mathrm{NH}_{4}^{+}\left(\delta^{15} \mathrm{DON}+\mathrm{NH}_{4}^{+}\right)$, nitrate $\left(\delta^{15} \mathrm{~N}-\mathrm{NO}_{3}^{-}\right)$and particulate nitrogen $\left(\delta^{15} \mathrm{PN}\right)$ in the non-tidal Elbe River (SE North Sea, NW Europe) over a period of $2 \mathrm{yr}$ (June 2005 to December 2007) at monthly resolution. Combined $\mathrm{DON}+\mathrm{NH}_{4}^{+}$concentrations ranged from 22 to $75 \mu \mathrm{M}$ and comprised nearly $23 \%$ of total dissolved nitrogen in the Elbe River in annual mean; PN and nitrate concentrations ranged from 11 to $127 \mu \mathrm{M}$, and 33 to $422 \mu \mathrm{M}$, respectively. Combined $\mathrm{PN}$ and $\mathrm{DON}+\mathrm{NH}_{4}^{+}$concentrations were, to a first approximation, inversely correlated to nitrate concentrations. $\delta^{15} \mathrm{DON}+\mathrm{NH}_{4}^{+}$, which varied between from $0.8 \%$ to $11.5 \%$, changed in parallel to $\delta^{15} \mathrm{PN}$ (range 6 to $10 \%$ ), and both were anti-correlated to $\delta^{15} \mathrm{~N}-\mathrm{NO}_{3}^{-}$(range 6 to $23 \%$ o). Seasonal patterns of $\mathrm{DON}+\mathrm{NH}_{4}^{+}$concentrations and $\delta^{15} \mathrm{DON}+\mathrm{NH}_{4}^{+}$diverge from those expected from biological $\mathrm{DON}+\mathrm{NH}_{4}^{+}$production in the river alone and suggest that the elution of organic fertilisers significantly affects the $\mathrm{DON}+\mathrm{NH}_{4}^{+}$pool in the Elbe River.
\end{abstract}

\section{Introduction}

Dissolved organic nitrogen (DON) is a major contributor to total dissolved nitrogen (TDN, the sum of nitrate, nitrite, ammonium and DON) discharged from land to the coastal ocean. Meybeck (1993) estimated that nearly $70 \%$ of the

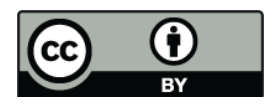

Correspondence to: K. Dähnke (kirstin.daehnke@hzg.de) nitrogen entering coastal regions via rivers is in the form of DON, and highest relative DON contributions characterize TDN loads of unpolluted rivers (Wiegner et al., 2006). But although DON comprises a smaller fraction than nitrate of the total $\mathrm{N}$ load in many eutrophied rivers, anthropogenic sources may significantly increase the natural DON background (Agedah et al., 2009; Howarth, 2004) up to a point where anthropogenic sources exceed wetland-derived DON in low-N streams (Stanley and Maxted, 2008). DON was long thought to be an inert pool of heterogeneous composition that is not a relevant $\mathrm{N}$-source for freshwater and estuarine ecosystems (Williams and Druffel, 1987), but recent work suggests that labile fractions of DON are selectively turned over in estuaries (Schlarbaum et al., 2010). When discharged to coastal seas, DON may substitute for dissolved inorganic nitrogen (DIN) as a substrate for phytoplankton assimilation. A substantially larger fraction of DON is assimilated by marine than by freshwater bacterioplankton; the susceptibility of DON to mineralization by bacteria appears to increase with increasing salinity during transport from fresh to marine water (Stepanauskas et al., 1999a, b). In seasons when the inorganic $\mathrm{N}$ pools are exhausted DON may in particular promote harmful algal blooms (Bronk, 2002).

The lack of knowledge on DON sources and turnover in rivers, as well as the potential influence of coastal ecosystems near river discharge areas motivated our investigation into DON dynamics in the Elbe river, possible seasonality of DON discharge into the adjacent estuary and coastal sea, and use of isotopic indicators for origin, as well as for possible sources and sinks of DON in the river.

As a sequel to a study on combined DON and ammonium dynamics in the Elbe estuary (Schlarbaum et al., 2010), we here present a data set on concentrations and the ${ }^{15} \mathrm{~N} /{ }^{14} \mathrm{~N}$ composition of combined DON and ammonium $\left(\mathrm{DON}+\mathrm{NH}_{4}^{+}\right)$, particulate nitrogen $(\mathrm{PN})$, and nitrate (expressed as the $\delta$ value in $\% o=\left[\left(R_{\text {sample }} / R_{\text {standard }}\right)-1\right] \times 1000$, $R={ }^{15} \mathrm{~N} /{ }^{14} \mathrm{~N}$ in $\mathrm{DON}+\mathrm{NH}_{4}^{+}$, nitrate, or $\mathrm{PN}$, and in the

Published by Copernicus Publications on behalf of the European Geosciences Union. 
international standard atmospheric dinitrogen) of the Elbe River. The first objective of this study is to investigate the seasonal pattern of combined DON and ammonium in the river that drains an intensely farmed ( $70 \%$ agriculture) catchment of $148268 \mathrm{~km}^{2}$ in central Europe, and in which policy measures, such as a ban on organic fertilizers from beginning of November to the end of January (DüV, 2009), potentially impose an external rhythm on possible allochtonous DON and ammonium sources. Secondly, we were interested in links between the DON and PN pools, which both may be products of phytoplankton assimilation of the dissolved inorganic nitrogen (DIN) load, or - in the case of DON - may originate from dissimilation of PN within the river. The data set is of monthly resolution and permits us to assess seasonal variations depending on internal cycling or external inputs, and turnover of reactive $\mathrm{N}$ between different pools.

\section{Materials and methods}

\subsection{Study site}

The Elbe River is $1094 \mathrm{~km}$ long and one of the largest rivers in Germany discharging into the North Sea. The weir at Geesthacht (built 1957-1959 AD) at stream kilometer 585 is the only barrage along the Elbe River and separates a tidal estuary from the upstream river system (Fig. 1). The average fresh water discharge at the weir Geesthacht is $700 \mathrm{~m}^{3} \mathrm{~s}^{-1}$, and can rise to $4000 \mathrm{~m}^{3} \mathrm{~s}^{-1}$ during floods; nearly 25 million people live in the entire catchment area of $148268 \mathrm{~km}^{2}$ (Behrendt et al., 2004). The Elbe River is the largest nutrient source of the German Bight (Brockmann and Pfeiffer, 1990), which is severely affected by eutrophication (OSPAR, 2008). In 2007, the Elbe discharged $87 \mathrm{kt}$ reactive $\mathrm{N}$ ( $85 \%$ nitrate, $15 \% \mathrm{DON}+\mathrm{NH}_{4}^{+}+\mathrm{PN}$ ) into the estuary (Arge, 2008).

\subsection{Sampling}

From June 2005 to December 2007, monthly water samples were collected at the weir using a Ruttner sampler. Initially, samples were collected at two different water depths $(0.5 \mathrm{~m}$ and $3 \mathrm{~m})$, which was reduced to only 1 sample from $1-2 \mathrm{~m}$ after initial analyses showed no significant difference between the two depths. The river water was immediately filtered through precombusted GF/F filters and stored in PE bottles that had been soaked in acid overnight and rinsed with deionised water (DIW). Each bottle was rinsed with sample water before being filled. Water samples were frozen at $-18^{\circ} \mathrm{C}$ until analysis. Filters were dried at $60-70{ }^{\circ} \mathrm{C}$ and stored at $4{ }^{\circ} \mathrm{C}$ before analyses.

\subsection{Methods}

Glassware was washed with deionised water (DIW), soaked in soap and $10 \% \mathrm{HCl}$ baths and washed again with DIW after each single step. All non-volumetric glassware was com-

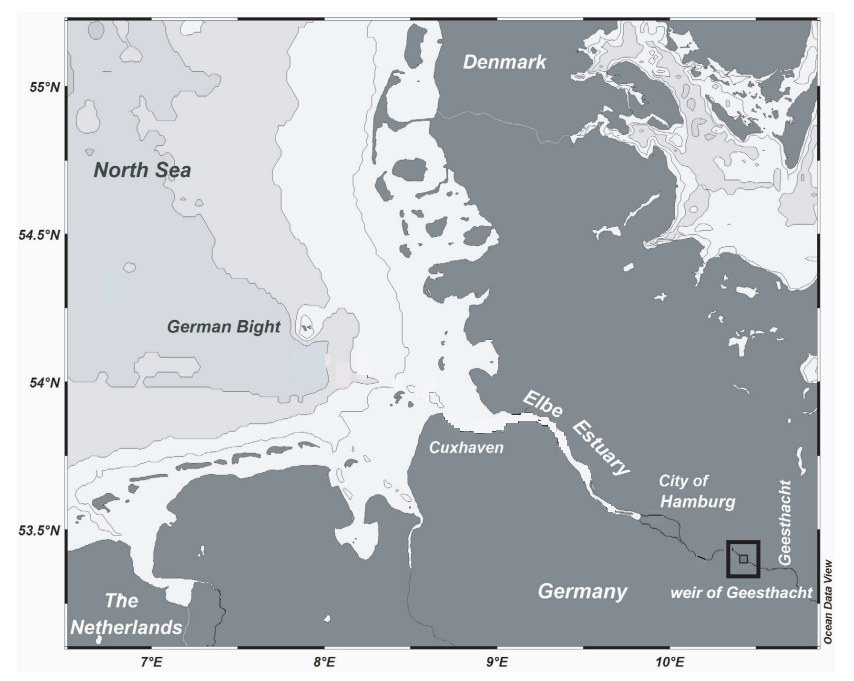

Fig. 1. Sample station weir of Geesthacht, Northern Germany, NW Europe.

busted at $450^{\circ} \mathrm{C}$ for at least $4 \mathrm{~h}$, volumetric glassware and PE-bottles were washed with DIW, soaked in $10 \% \mathrm{HCl}$ bath overnight, washed again with DIW and dried at $50^{\circ} \mathrm{C}$.

Concentration of total dissolved nitrogen (TDN) in DIW was determined using the "persulfate oxidation method" (Solórzano and Sharp, 1980; Koroleff, 1976; Knapp et al., 2005) (see below) with a blank of $<1 \mu \mathrm{mol} 1^{-1}$.

\subsubsection{Concentrations and $\delta^{15} \mathrm{~N}$ analysis of Nitrate and Nitrite}

Concentrations of nitrate and nitrite were measured with standard colorimetric techniques (Grasshoff et al., 1999) on an AutoAnalyzer 3 (Bran \& Luebbe). Concentration of nitrite in the water samples was negligible (below $2 \%$ of the nitrate concentration) at a detection limit of $0.05 \mu \mathrm{M}$. $\delta^{15} \mathrm{~N}-\mathrm{NO}_{3}^{-}$was analysed with the denitrifier method (Sigman et al., 2001; Casciotti et al., 2002). In brief, nitrate was quantitatively reduced to nitrous oxide $\left(\mathrm{N}_{2} \mathrm{O}\right)$ by using a strain of denitrifier bacteria that lacks $\mathrm{N}_{2} \mathrm{O}$ reductase activity. $\mathrm{N}_{2} \mathrm{O}$ was automatically extracted, purified in a Gasbench (ThermoFinnigan) and analysed on a Finnigan Delta plus XP mass spectrometer. The sample size was adjusted to $20 \mathrm{nmol}$ nitrate in each sample. The samples were referenced to injections of $\mathrm{N}_{2} \mathrm{O}$ from a pure $\mathrm{N}_{2} \mathrm{O}$ gas cylinder and then standardised using an internationally accepted nitrate isotopic reference material (IAEA-N $3, \delta^{15} \mathrm{~N}=4.7 \%$ ). We used an internal potassium nitrate standard for further validation of our results, which we measured with each batch of samples. The standard deviation for replicate analyses $(n=4)$ was $\pm 0.2 \%$. The method also permits determination of $\delta^{18} \mathrm{O}-\mathrm{NO}_{3}^{-}$(Sigman et al., 2001; Casciotti et al., 2002; Dähnke et al., 2008), which is referenced to IAEA-N3 with a $\delta^{18} \mathrm{O}-\mathrm{NO}_{3}^{-}$of $22.7 \%$ oversus Vienna Standard Mean 
Ocean Water (VSMOW) (Böhlke et al., 2003). We note that this value has recently been corrected and is now reported as $25.6 \%$, but for an easier comparison with earlier studies (Johannsen et al., 2008; Schlarbaum et al., 2010), we decided to use the formerly assigned value.

\subsubsection{Concentration and $\delta^{15} \mathrm{~N}$ analysis of TDN}

To determine the TDN concentration and $\delta^{15} \mathrm{TDN}$ we used the method of Knapp et al. (2005), with small modifications as described in Schlarbaum et al. (2010). In brief, total dissolved nitrogen is oxidized to nitrate using the "persulfate oxidation method" (Solórzano and Sharp, 1980; Koroleff, 1976; Knapp et al., 2005). Concentration of TDN was determined as nitrate after oxidation by the method described above.

For the determination of $\delta^{15} \mathrm{TDN}$, nitrate in oxidised samples and reagent blanks was converted to $\mathrm{N}_{2} \mathrm{O}$ using the denitrifier method (Sigman et al., 2001; Casciotti et al., 2002) as described above.

\subsubsection{Concentration and $\delta^{15} \mathrm{~N}$ analysis of combined $\mathrm{DON}+\mathrm{NH}_{4}^{+}$}

Concentration of combined DON $+\mathrm{NH}_{4}^{+}$was calculated by the difference between TDN and nitrate, because concentration of nitrite was consistently negligible.

For the $\delta^{15} \mathrm{DON}+\mathrm{NH}_{4}^{+}$mass balance calculations were made using the measured nitrate concentrations and $\delta^{15} \mathrm{~N}$ values of the oxidised sample, the reagent blank and the unoxidised sample:

$$
\begin{aligned}
\delta^{15} \mathrm{DON} & +\mathrm{NH}_{4}^{+}=\delta^{15} \mathrm{TDN} \cdot c(\mathrm{TDN}) / c\left(\mathrm{DON}+\mathrm{NH}_{4}^{+}\right) \\
& -\left[\delta^{15} \mathrm{~N}-\mathrm{NO}_{3}^{-} \cdot c\left(\mathrm{NO}_{3}^{-}\right)\right. \\
& \left.+\delta^{15} \mathrm{~N}_{\text {Blank }} \cdot c(\text { Blank })\right] / c\left(\mathrm{DON}+\mathrm{NH}_{4}^{+}\right)
\end{aligned}
$$

The combination of persulfate digestion and denitrifier method to measure $\delta^{15} \mathrm{DON}+\mathrm{NH}_{4}^{+}$has been tested by oxidation of urea standard solutions with a concentration range of 10 to $400 \mu \mathrm{M}$. The $\delta^{15} \mathrm{~N}$ of solid urea was measured by using a Flash EA 1112 elemental analyzer coupled to a Finnigan Delta plus XP mass spectrometer, yielding a $\delta^{15} \mathrm{~N}$ value of $0.5 \% \circ \pm 0.2 \%$. Measurements of the urea solutions after preparation as above yielded in $\delta^{15} \mathrm{~N}$ values of $0.4 \%$ \% $\pm .2 \%$ after blank correction.

Repeated measurements of the same water sample demonstrated the reproducibility of the $\delta^{15} \mathrm{~N}$ method for $\delta^{15} \mathrm{DON}+\mathrm{NH}_{4}^{+}$analyses. The mean measured standard deviation of $\delta^{15} \mathrm{TDN}$ and $\delta^{15} \mathrm{~N}-\mathrm{NO}_{3}^{-}$was $0.2 \%$ ( 3 to 4 repetitions). The mean standard deviation for TDN and nitrate concentration was $1 \mu \mathrm{M}$. Because of error propagation, the calculated standard deviation of $\delta^{15} \mathrm{DON}+\mathrm{NH}_{4}^{+}$ranged from 0.1 to $2.8 \%$ with a mean value of $1.2 \%$, and the calculated mean standard deviation for combined $\mathrm{DON}+\mathrm{NH}_{4}^{+}$concentration was $2.2 \mu \mathrm{M}$.
The method does not separate DON and ammonium. However, in comparison with DON concentration, ammonium concentrations were near to or below detection limit $(<2.9 \mu \mathrm{M})$ except for samples taken during winter seasons and in June 2007. During winter seasons, ammonium concentrations occasionally increased up to $34 \mu \mathrm{M}$ (February 2006), equalling $50 \%$ of the combined $\mathrm{DON}+\mathrm{NH}_{4}^{+}$ loads; in June 2007, ammonium accounted for approximately $10 \%$ of combined $\mathrm{DON}+\mathrm{NH}_{4}^{+}$.

\subsubsection{Concentration and $\delta^{15} \mathrm{~N}$ analysis of PN}

Particulate nitrogen was sampled by filtering the water samples through precombusted $\left(6 \mathrm{~h}, 450^{\circ} \mathrm{C}\right)$ and tared $\mathrm{GF} / \mathrm{F}$ filters. After filtration the filters were dried at $60^{\circ} \mathrm{C}$ and stored dark at $4{ }^{\circ} \mathrm{C}$ until analysed. The weight of particulate matter on the filters was determined, and $\mathrm{C}$ and $\mathrm{N}$ weight $\%$ were analysed by using a Flash EA 1112 elemental analyzer. The $\delta^{15} \mathrm{PN}$ was analysed with a Flash EA 1112 elemental analyzer coupled to a Finnigan Delta plus XP mass spectrometer. Results were standardised using the internationally accepted isotopic reference materials "High organic sediment standard OAS" (Cat. no. B2151, Batch no. $2824, \delta^{15} \mathrm{~N}=+4.4 \%$ o $0.19 \%$ ), "Low Organic Content Soil Standard OAS" (Cat. no. B2153, Batch no. 2822, $\left.\delta^{15} \mathrm{~N}=+6.7 \% \circ \pm 0.15 \% \circ\right)$ and IAEA-N1 $\left(\delta^{15} \mathrm{~N}=+0.4 \% \circ\right)$. The standard deviation for replicate analysis was $0.2 \%$ o (3 replicates).

\subsection{Annual and seasonal loads and load-weighted isotopic values}

For an estimate of the mass loads of $\mathrm{DON}+\mathrm{NH}_{4}^{+}$, TDN, $\mathrm{PN}$, and nitrate and the average $\mathrm{N}$-isotope composition of these compounds, we used our analytical data and the discharge rates of the sampling dates to calculate annual loads $(L)$ as:

$L=\sum\left|J_{i}\right| \cdot c_{i} \cdot$ flow $_{i}$

The entire time interval $J$ of 12 months for annual calculations ( 6 months for seasonal calculations) was divided in $n$ sampling intervals with the duration $\left|J_{i}\right|$, the concentration $c_{i}$ and the discharge flow $_{i}$. The annual load $L$ is the sum of the single loads in the sampling intervals $J_{i}$ (Hebbel and Steuer, 2006; Johannsen et al., 2008).

For the calculation of the load-weighted annual average isotope composition, the isotope values were multiplied with the respective concentration and weighted with the loads according to the formulas

$\delta^{15} \mathrm{~N}_{\mathrm{wml}}=\sum \delta^{15} \mathrm{~N}_{i} \cdot c_{i} \cdot$ flow $_{i} / \sum c_{i} \cdot$ flow $_{i}$

$\delta^{18} \mathrm{O}_{\mathrm{wml}}=\sum \delta \delta^{18} \mathrm{O}_{i} \cdot c_{i} \cdot$ flow $_{i} / \sum \cdot c_{i} \cdot$ flow $_{i}$

where $\delta^{15} \mathrm{~N}_{\mathrm{wml}}$ and $\delta^{18} \mathrm{O}_{\mathrm{wml}}$ are the load-weighted annual isotope values, $\delta^{15} \mathrm{~N}_{i}$ and $\delta^{18} \mathrm{O}_{i}$ are the measured isotope values of individual samples, $c_{i}$ is the respective concentration, and flow $i$ the discharge flow. 


\section{Results}

The analytical results from sampling in the period June 2005 to December 2007 are plotted in Fig. 2. Water discharge for the sampling dates were plotted as bars and show an exceptional spring flood in April 2006. In the first 6 months of sampling, we determined only concentrations and $\delta^{15} \mathrm{~N}$ of nitrate and $\mathrm{DON}+\mathrm{NH}_{4}^{+}$; the last two years, measurements included also $\delta^{18} \mathrm{O}-\mathrm{NO}_{3}^{-}$, and concentrations and $\delta^{15} \mathrm{PN}$ (from July 2006 to December 2007).

\subsection{Nitrate concentrations and isotopic compositions}

Throughout the entire sampling period covered in our current study, nitrate displays a clear seasonal trend in concentrations and isotopic composition. $\delta^{15} \mathrm{~N}-\mathrm{NO}_{3}^{-}$and $\delta^{18} \mathrm{O}-\mathrm{NO}_{3}^{-}$ were both enriched during summer months (maxima $23 \%$ o and $12 \%$, respectively) and were both depleted during winter times (minima $6 \% \circ$ and $<1 \%$, respectively) (Fig. 2a) and are anti-correlated $\left(r^{2}=0.84, r=-0.92, \alpha \leq 0.01\right)$ (Table 1) to nitrate concentrations (min. $30 \mu \mathrm{M}$ in summer seasons, max. $420 \mu \mathrm{M}$ in winter seasons). $\delta^{15} \mathrm{~N}-\mathrm{NO}_{3}^{-}$and $\delta^{18} \mathrm{O}-\mathrm{NO}_{3}^{-}$varied almost parallel and are strongly correlated $\left(r^{2}=0.96, r=0.98, \alpha \leq 0.01\right.$, Table 1$)$. A plot of $\delta^{18} \mathrm{O}$ vs. $\delta^{15} \mathrm{~N}$ shows that the isotope values plot on a slope of $0.81: 1$, (Fig. 3). Nitrate concentration and isotopic composition from January 2006 to December 2006 are also published in Johannsen et al. (2008).

\subsection{DON $+\mathrm{NH}_{4}^{+}$concentrations and isotopic compositions}

$\mathrm{DON}+\mathrm{NH}_{4}^{+}$concentrations also showed a distinct seasonality: concentrations varied between $22 \mu \mathrm{M}$ and $76 \mu \mathrm{M}$, $\delta^{15} \mathrm{DON}+\mathrm{NH}_{4}^{+}$ranged from $1 \%$ in November 2006 to $12 \%$ in March 2006 (Fig. 2b). We found two distinct maxima in both concentration and $\delta^{15} \mathrm{DON}+\mathrm{NH}_{4}^{+}$per year. The first maximum with higher values in both concentration and $\delta^{15} \mathrm{DON}+\mathrm{NH}_{4}^{+}$appeared in winter months (from December to March), the second in summer; minima occurred during spring and autumn seasons. Unlike nitrate, $\delta^{15} \mathrm{DON}+\mathrm{NH}_{4}^{+}$ and $\mathrm{DON}+\mathrm{NH}_{4}^{+}$concentration are only loosely correlated $\left(r^{2}=0.35, r=0.59, \alpha \leq 0.01\right.$, Table 1$)$.

\section{3 $\mathrm{DON}+\mathrm{NH}_{4}^{+} / \mathrm{TDN}$ ratios}

The $\mathrm{DON}+\mathrm{NH}_{4}^{+}$contribution to TDN differs through seasons (Table 2), with an annual average of $\left(\mathrm{DON}+\mathrm{NH}_{4}^{+}\right) / \mathrm{TDN}$ of $23 \%$. The highest $\left(\mathrm{DON}+\mathrm{NH}_{4}^{+}\right) / \mathrm{TDN}$ ratio occurred in August 2006 (57\%), the lowest in March 2006 (8\%, Table 2). On average, the $\left(\mathrm{DON}+\mathrm{NH}_{4}^{+}\right) / \mathrm{TDN}$ ratio in summer is about twice as high as in seasons with less biologic activity (33\% versus $15 \%$ in winter, $18 \%$ in spring and $17 \%$ in autumn).

\subsection{Particulate nitrogen}

Concentrations of PN peaked in spring/summer, and $\delta^{15} \mathrm{PN}$ fluctuated in a small range of 6 to $10 \%$ (Fig. 2c). High concentrations of PN were found in spring and summer seasons $(55.0-65.6 \mu \mathrm{M})$ while lower concentrations (20.2$41.4 \mu \mathrm{M})$ were detected in samples from winter and autumn seasons. PN thus shows a similar seasonal cycle as nitrate, but varies in a considerably smaller range. In contrast to nitrate, no significant anti-correlation between $\delta^{15} \mathrm{PN}$ and PN concentration was evident $\left(r^{2}=0.14, r=-0.30, \alpha>0.05\right.$, Table 1). $\delta^{15} \mathrm{PN}$ has a distinct seasonal pattern with one peak at times of biological production and another peak in winter. In comparison to $\delta^{15} \mathrm{DON}+\mathrm{NH}_{4}^{+}, \delta^{15} \mathrm{PN}$ is higher but closely tracks $\delta^{15} \mathrm{DON}+\mathrm{NH}_{4}^{+}$(Fig. 4), with a correlation of $r^{2}=0.53(r=0.73, \alpha \leq 0.01)$ between these two parameters (Fig. 5).

\subsection{Loads and annual isotopic values}

The annual loads transported in the Elbe River and discharged into the downstream estuary at the weir of Geesthacht are listed in Table 3. The annual TDN loads were $107 \mathrm{kt}$ in 2006 and $72 \mathrm{kt}$ in 2007. An unusual flood in April 2006 caused high discharge at high concentrations, and created the nearly $50 \%$ difference in total dissolved nitrogen loads between the two years.

Excluding the anomalous flood data, a clear seasonal pattern of higher loads in winter seasons (October to March) emerges: in the case of nitrate, the winter load is more than three times the summer load, and for $\mathrm{DON}+\mathrm{NH}_{4}^{+}$the winter load is twice as high. In contrast, the PN load is relatively constant throughout the year.

Table 4 lists the results of load-weighted annual isotope values for $\mathrm{DON}+\mathrm{NH}_{4}^{+}$, TDN, nitrate and $\mathrm{PN}$ in addition to seasonal load-weighted isotope values. The seasonal diffenences are partly obscured by the extraordinary spring flood in April 2006, but overall, dual nitrate isotope values were higher in summer $\left(\delta^{15} \mathrm{~N}-\mathrm{NO}_{3}^{-}: 8.1 \%\right.$ o- $18.7 \%$; $\left.\delta^{18} \mathrm{O}-\mathrm{NO}_{3}^{-}: 1.6 \% \%_{-}-6.6 \%\right)$ than in winter $\left(\delta^{15} \mathrm{~N}-\mathrm{NO}_{3}^{-}\right.$: $8.8 \% 0-9.5 \% ; \delta^{18} \mathrm{O}-\mathrm{NO}_{3}^{-}: 0.7 \% o-1.1 \%$ o). If the spring flood data in 2006 are excluded from the calculation of load weighted seasonal means, the spring/summer signal for that year rises from the minimum value $\delta^{15} \mathrm{~N}-\mathrm{NO}_{3}^{-}=8.1$ to $11.0 \%$. For the particulate loads, $\delta^{15} \mathrm{PN}$ showed lower values in summer seasons $\left(4.8 \% \%^{-7.1 \% o}\right)$ than in winter seasons $(8.2 \%-8.4 \%$ )

Combined $\delta^{15} \mathrm{DON}+\mathrm{NH}_{4}^{+}$values were also lower in summer $(5.0 \% o-5.9 \% o)$ than in winter $\left(6.3 \% 0^{-7.5 \% o}\right)$; the isotopic differences between summer and winter seasons were much smaller than for nitrate and PN. Because of the greater share of nitrate in TDN, $\delta^{15}$ TDN followed the same trend as $\delta^{15} \mathrm{~N}-\mathrm{NO}_{3}^{-}$with the higher values in summer seasons $\left(10.3 \%\right.$ o $-14.5 \%$ ) compared to winter seasons $\left(8.6 \% o_{-}\right.$ $9.1 \% 0)$. 

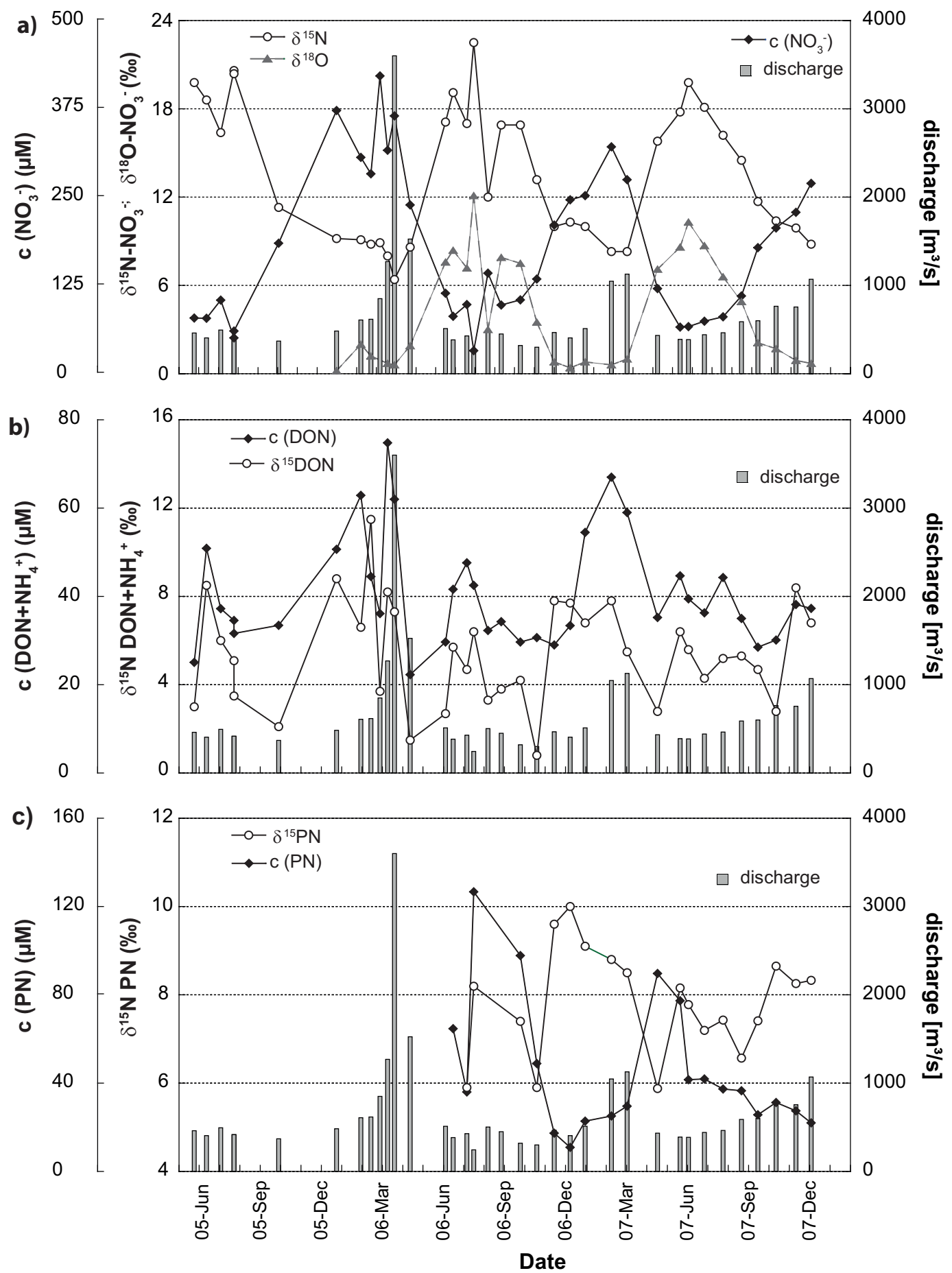

Fig. 2. Concentration and isotopic values in the Elbe River at the weir of Geesthacht, June 2005-December 2007, bars represent the river discharge. Note the different scales of the y-axes. (a) Nitrate concentration, $\delta^{15} \mathrm{~N}-\mathrm{NO}_{3}^{-}$and $\delta^{18} \mathrm{O}-\mathrm{NO}_{3}^{-}$in the Elbe River. Data from 2006 have been published in Johannsen et al. (2008). (b) combined DON $+\mathrm{NH}_{4}^{+}$concentration and $\delta^{15} \mathrm{DON}+\mathrm{NH}_{4}^{+}$. (c) $\mathrm{PN}$ concentration and $\delta^{15} \mathrm{PN}$. 
Table 1. Correlation coefficients of all measured parameters in the Elbe River at the weir of Geesthacht, June 2005-December 2007. $r^{2}$ in bold, underlined coefficients present a level of significance $\alpha \leq 0.01$.

\begin{tabular}{|c|c|c|c|c|c|c|c|c|c|}
\hline$r^{2} / r$ & $\begin{array}{c}c \\
\left(\mathrm{NO}_{3}^{-}\right) \\
\end{array}$ & $\begin{array}{c}c \\
(\mathrm{TDN})\end{array}$ & $\begin{array}{c}c \\
\left(\mathrm{DON}+\mathrm{NH}_{4}^{+}\right) \\
\end{array}$ & $\begin{array}{l}c \\
(\mathrm{PN})\end{array}$ & $\begin{array}{r}\delta^{15} \mathrm{~N} \\
-\mathrm{NO}_{3}^{-} \\
\end{array}$ & $\begin{array}{r}\delta^{18} \mathrm{O} \\
-\mathrm{NO}_{3}^{-} \\
\end{array}$ & $\delta^{15} \mathrm{TDN}$ & $\begin{array}{r}\delta^{15} \mathrm{DON} \\
+\mathrm{NH}_{4}^{+} \\
\end{array}$ & $\delta^{15} \mathrm{PN}$ \\
\hline$c\left(\mathrm{NO}_{3}^{-}\right)$ & & $\underline{0.995}$ & $\underline{0.462}$ & -0.674 & -0.918 & -0.897 & -0.902 & 0.369 & $\underline{0.584}$ \\
\hline$c(\mathrm{TDN})$ & 0.991 & & $\overline{0.547}$ & $\overline{-0.656}$ & $\overline{-0.907}$ & $\overline{-0.868}$ & $\overline{-0.898}$ & 0.414 & $\overline{0.579}$ \\
\hline$c\left(\mathrm{DON}+\mathrm{NH}_{4}^{+}\right)$ & $\overline{0.214}$ & 0.299 & & $\overline{-0.104}$ & $\overline{-0.359}$ & $\overline{-0.278}$ & $\overline{-0.424}$ & 0.592 & $\overline{0.193}$ \\
\hline$c(\mathrm{PN})$ & $\overline{0.454}$ & $\overline{0.431}$ & 0.011 & & $\underline{0.745}$ & $\underline{0.770}$ & $\underline{0.655}$ & $-\overline{0.296}$ & -0.375 \\
\hline$\delta^{15} \mathrm{~N}-\mathrm{NO}_{3}^{-}$ & $\underline{0.843}$ & $\underline{0.822}$ & 0.129 & $\underline{0.555}$ & & 0.977 & 0.964 & -0.287 & -0.487 \\
\hline$\delta^{18} \mathrm{O}-\mathrm{NO}_{3}^{-}$ & $\overline{0.805}$ & $\overline{0.754}$ & 0.077 & $\overline{0.593}$ & $\underline{0.955}$ & & $\overline{0.916}$ & -0.380 & -0.496 \\
\hline$\delta^{15} \mathrm{TDN}$ & $\underline{0.813}$ & $\underline{0.807}$ & 0.179 & 0.429 & 0.930 & $\underline{0.840}$ & & -0.275 & -0.552 \\
\hline$\delta^{15} \mathrm{DON}+\mathrm{NH}_{4}^{+}$ & 0.136 & 0.171 & $\underline{0.351}$ & 0.088 & 0.082 & 0.144 & 0.076 & & $\underline{0.726}$ \\
\hline$\delta^{15} \mathrm{PN}$ & $\underline{0.341}$ & $\underline{0.336}$ & 0.037 & 0.141 & 0.237 & 0.246 & 0.305 & $\underline{0.528}$ & \\
\hline
\end{tabular}

Table 2. Annual and seasonal mean concentrations and mean isotope values of nitrate, $\mathrm{TDN}, \mathrm{DON}+\mathrm{NH}_{4}^{+}$and $\mathrm{PN}$, and annual and seasonal mean $\mathrm{DON}+\mathrm{NH}_{4}^{+}$ratio in the Elbe River at the weir of Geesthacht, June 2005-December 2007.

\begin{tabular}{|c|c|c|c|c|c|c|c|c|c|c|}
\hline & $\begin{array}{r}c\left(\mathrm{NO}_{3}^{-}\right) \\
{[\mu \mathrm{M}]}\end{array}$ & $\begin{array}{r}c(\mathrm{TDN}) \\
{[\mu \mathrm{M}]}\end{array}$ & $\begin{array}{r}c\left(\mathrm{DON}+\mathrm{NH}_{4}^{+}\right) \\
{[\mu \mathrm{M}]}\end{array}$ & $\begin{array}{r}c(\mathrm{PN}) \\
{[\mu \mathrm{M}]}\end{array}$ & $\begin{array}{r}\left(\mathrm{DON}+\mathrm{NH}_{4}^{+}\right) / \mathrm{TDN} \\
{[\%]}\end{array}$ & $\begin{array}{r}\delta^{15} \mathrm{~N}-\mathrm{NO}_{3}^{-} \\
{[\% \circ]}\end{array}$ & $\begin{array}{r}\delta^{18} \mathrm{O}-\mathrm{NO}_{3}^{-} \\
{[\% o]}\end{array}$ & $\begin{array}{r}\delta^{15} \mathrm{TDN} \\
{[\% o]}\end{array}$ & $\begin{array}{r}\delta^{15} \mathrm{DON}+\mathrm{NH}_{4}^{+} \\
{[\% \%]}\end{array}$ & $\begin{array}{r}\delta^{15} \mathrm{PN} \\
{[\% o]}\end{array}$ \\
\hline $\begin{array}{l}\text { summer half-year } \\
\text { (Apr-Sep) }\end{array}$ & $112 \pm 76$ & $150 \pm 78$ & $38 \pm 9$ & $57 \pm 32$ & $29.1 \pm 11.4$ & $16.5 \pm 4.1$ & $6.5 \pm 3.3$ & $12.8 \pm 2.3$ & $4.8 \pm 1.7$ & $7.2 \pm 0.9$ \\
\hline $\begin{array}{l}\text { winter half-year } \\
\text { (Oct-Mar) }\end{array}$ & $258 \pm 82$ & $303 \pm 91$ & $45 \pm 15$ & $33 \pm 25$ & $15.1 \pm 3.6$ & $10.1 \pm 2.2$ & $1.6 \pm 1.9$ & $9.5 \pm 1.5$ & $6.2 \pm 2.8$ & $8.5 \pm 1.1$ \\
\hline $\begin{array}{l}\text { winter } \\
\text { (Dec-Feb) }\end{array}$ & $295 \pm 48$ & $346 \pm 56$ & $51 \pm 14$ & $20 \pm 6$ & $14.7 \pm 2.9$ & $9.3 \pm 0.7$ & $0.8 \pm 0.6$ & $9.0 \pm 0.7$ & $7.4 \pm 0.9$ & $9.1 \pm 0.7$ \\
\hline $\begin{array}{l}\text { spring } \\
\text { (Mar-May) }\end{array}$ & $261 \pm 119$ & $308 \pm 125$ & $47 \pm 17$ & $66 \pm 32$ & $18.0 \pm 10.3$ & $10.3 \pm 4.1$ & $3.0 \pm 3.4$ & $9.3 \pm 2.4$ & $5.9 \pm 3.2$ & $7.5 \pm 1.4$ \\
\hline $\begin{array}{l}\text { summer } \\
\text { (Jun-Aug) }\end{array}$ & $84 \pm 28$ & $122 \pm 28$ & $38 \pm 7$ & $55 \pm 33$ & $32.6 \pm 9.8$ & $18.0 \pm 2.7$ & $7.6 \pm 2.7$ & $13.7 \pm 1.3$ & $4.9 \pm 1.6$ & $7.2 \pm 0.8$ \\
\hline $\begin{array}{l}\text { autumn } \\
\text { (Sep-Nov) }\end{array}$ & $168 \pm 50$ & $200 \pm 51$ & $32 \pm 3$ & $41 \pm 30$ & $16.9 \pm 5.0$ & $12.5 \pm 2.9$ & $3.5 \pm 3.0$ & $11.0 \pm 1.8$ & $4.3 \pm 2.6$ & $7.9 \pm 1.3$ \\
\hline annual mean & $177 \pm 107$ & $218 \pm 113$ & $41 \pm 12$ & $46 \pm 30$ & $22.9 \pm 11.2$ & $13.6 \pm 4.6$ & $4.1 \pm 3.7$ & $11.3 \pm 2.6$ & $5.4 \pm 2.4$ & $7.8 \pm 1.2$ \\
\hline Max & 422 & 458 & 75 & 127 & 56.6 & 22.5 & 12.1 & 15.8 & 11.5 & 10.0 \\
\hline Min & 33 & 75 & 22 & 11 & 7.9 & 6.4 & 0.2 & 6.5 & 0.8 & 5.9 \\
\hline
\end{tabular}

\section{Discussion}

Our results show the composition of total nitrogen and the isotopic composition of different reactive $\mathrm{N}$ sources in the Elbe River over a time period of more than $2 \mathrm{yr}$ from June 2005 to December 2007. In the next section we will discuss the data for nitrate, combined $\mathrm{DON}+\mathrm{NH}_{4}^{+}$and $\mathrm{PN}$ under the aspects of seasonality and correlations between the measured parameters. We wanted to investigate whether (a) biological processes within the river or (b) external forcing influences the seasonal dynamics of dissolved nitrogen isotopes at Geesthacht weir. Furthermore we wanted investigate the correlations of the different $\mathrm{N}$ pools (nitrate, $\mathrm{DON}+\mathrm{NH}_{4}^{+}$and $\mathrm{PN}$ ) since these are subject to complex interactions. DON can be a product or source of phytoplankton assimilation; and $\mathrm{DON}+\mathrm{NH}_{4}^{+}$may also originate from dissimilation of $\mathrm{PN}$ within the river.

\subsection{Nitrate}

Nitrate concentrations were high in winter seasons and low in summer seasons and the isotopic composition of $\delta^{15} \mathrm{~N}-\mathrm{NO}_{3}^{-}$and $\delta^{18} \mathrm{O}-\mathrm{NO}_{3}^{-}$, had maxima during summer seasons and minima during winter seasons (Fig. 2a). Two parameters have a strong influence on nitrate load: discharge - which coincides with substantial elution of nitrate from arable land - and changes in biological activity in the water column. The importance of discharge is demonstrated in spring 2006, when the extraordinary spring flood led to high nitrate loads and unusually low nitrate isotope values (Fig. 2a), but further implications will be discussed below. The other important parameter, biological turnover, is known to be linked to significant isotopic fractionation, because organisms usually preferentially incorporate light isotopes $\left({ }^{14} \mathrm{~N},{ }^{16} \mathrm{O}\right)$ and discriminate against heavy isotopes, leaving 
Table 3. Annual and seasonal loads (in kt) of nitrate, TDN, DON $+\mathrm{NH}_{4}^{+}$and $\mathrm{PN}$ in the Elbe River at the weir of Geesthacht, June 2005December 2007 (n.d. = not determined).

\begin{tabular}{lrrrrrrrr}
\hline & $\begin{array}{r}\text { summer } \\
2005 \\
\text { (Jun-Sep) }\end{array}$ & $\begin{array}{r}\text { winter } \\
2005 / 2006 \\
\text { (Oct-Mar) }\end{array}$ & $\begin{array}{r}\text { summer } \\
2006 \\
\text { (Apr-Sep) }\end{array}$ & $\begin{array}{r}\text { winter } \\
2006 / 2007 \\
\text { (Oct-Mar) }\end{array}$ & $\begin{array}{r}\text { summer } \\
2007 \\
\text { (Apr-Sep) }\end{array}$ & $\begin{array}{r}\text { winter } \\
2007 \\
\text { (Oct-Dec) }\end{array}$ & $\begin{array}{r}\text { annual } \\
\text { load 2006 }\end{array}$ & $\begin{array}{r}\text { annual } \\
\text { load 2007 }\end{array}$ \\
\hline TDN Load [kt] & 12.02 & 58.73 & 63.26 & 39.59 & 14.84 & 52.18 & 107.11 & 72.03 \\
$\mathrm{NO}_{3}^{-}$Load [kt] & 8.67 & 50.35 & 53.55 & 32.97 & 10.97 & 45.44 & 91.19 & 59.16 \\
$\mathrm{DON}^{+} \mathrm{NH}_{4}^{+}$Load [kt] & 3.35 & 8.38 & 9.71 & 6.62 & 3.87 & 6.74 & 15.92 \\
PN Load [kt] & n.d. & n.d. & 5.27 & 4.09 & 5.00 & 5.01 & 8.20 & 12.87 \\
\hline
\end{tabular}

Table 4. Load weighted annual and seasonal mean isotope values of nitrate, TDN, DON $+\mathrm{NH}_{4}^{+}$and PN in the Elbe River at the weir of Geesthacht, June 2005-December 2007 (n.d. = not determined).

\begin{tabular}{|c|c|c|c|c|c|c|c|c|}
\hline & $\begin{array}{r}\text { summer } \\
2005 \\
\text { (Jun-Sep) }\end{array}$ & $\begin{array}{r}\text { winter } \\
2005 / 2006 \\
\text { (Oct-Mar) }\end{array}$ & $\begin{array}{r}\text { summer } \\
2006 \\
\text { (Apr-Sep) }\end{array}$ & $\begin{array}{r}\text { winter } \\
2006 / 2007 \\
\text { (Oct-Mar) }\end{array}$ & $\begin{array}{r}\text { summer } \\
2007 \\
\text { (Apr-Sep) }\end{array}$ & $\begin{array}{r}\text { winter } \\
2007 \\
\text { (Oct-Dec) }\end{array}$ & $\begin{array}{c}\text { annual } \\
\text { load } 2006\end{array}$ & $\begin{array}{r}\text { annual } \\
\text { load } 2007\end{array}$ \\
\hline$\delta^{15} \mathrm{TDN}$ wml & 14.5 & 8.6 & 7.7 & 8.8 & 12.4 & 9.1 & 8.3 & 9.4 \\
\hline$\delta^{15} \mathrm{~N}-\mathrm{NO}_{3}^{-} \mathrm{wml}$ & 18.7 & 8.8 & 8.1 & 9.3 & 15.0 & 9.5 & 8.6 & 10.2 \\
\hline$\delta^{18} \mathrm{O}-\mathrm{NO}_{3}^{-} \mathrm{wml}$ & n.d. & 0.7 & 1.6 & 1.1 & 5.6 & 1.0 & 1.3 & 1.8 \\
\hline$\delta^{15} \mathrm{DON}+\mathrm{NH}_{4}^{+} \mathrm{wml}$ & 5.6 & 7.5 & 5.9 & 6.5 & 5.0 & 6.3 & 6.5 & 6.0 \\
\hline$\delta^{15} \mathrm{PN}$ wml & n.d. & n.d. & 4.8 & 8.2 & 7.1 & 8.4 & 6.0 & 7.1 \\
\hline
\end{tabular}

the residual pool subsequently enriched in heavier isotope species (Kendall, 1998). An exception is sedimentary denitrification: though probably important in the Elbe River, this process has no apparent isotope effect on water column nitrate (Brandes and Devol, 2002; Lehmann et al., 2003) and will thus not be addressed in this study.

One potentially important process with notable fractionation is nitrate assimilation: at higher temperatures in summer, increased phytoplankton productivity leads to an enrichment of heavy isotopes $\left({ }^{15} \mathrm{~N}\right.$, respectively $\left.{ }^{18} \mathrm{O}\right)$ in the residual nitrate (Johannsen et al., 2008; Kendall, 1998). Granger et al. (2004) investigated the coupled nitrogen and oxygen isotope fractionation during nitrate assimilation by phytoplankton and found that assimilation should occur with equal fractionation factors of both elements, resulting in a slope of 1 . Another process that equally raises $\delta^{15} \mathrm{~N}-\mathrm{NO}_{3}^{-}$and $\delta^{18} \mathrm{O}-\mathrm{NO}_{3}^{-}$is water column denitrification, which strongly discriminates against the heavy isotopes, but this process is unlikely given the oxygen concentrations in the study area. We thus expect that assimilation will be the main driving force for isotopic fractionation at our study site. In Fig. 3 we plotted $\delta^{15} \mathrm{~N}-\mathrm{NO}_{3}^{-}$versus $\delta^{18} \mathrm{O}-\mathrm{NO}_{3}^{-}$and obtain a slope of 0.81 , which indeed points towards phytoplankton assimilation as one of the most important turnover pathways in the Elbe water column (Fig. 3). This is in agreement with data by Deutsch et al. (2009), who measured a ratio of 1.12 in the
Elbe River in July 2005. In combination with increased concentrations of chlorophyll- $a$ and particulate organic carbon they demonstrated that nitrate assimilation by phytoplankton plays a major role in nitrogen transformation processes in the Elbe River (Deutsch et al., 2009).

The difference in the determined slopes ( 0.8 in our study vs. 1.1 in the study by Deutsch et al., 2009) is noteworthy: in contrast to the cited work, we did not follow a Lagrangian sampling scheme, and external inputs of nitrate most likely play a role in the nitrate pool. Diffuse inputs of nitrate are dominated by groundwater (Ladwig, 2010), and denitrification in such environments fractionates differently for oxygen and nitrogen isotopes, following a slope of 0.5 (Böttcher et al., 1990). An impact of groundwater - related to infall and river discharge - would thus explain our slightly deviating results, suggesting that both processing in the river itself and in the aquifers can influence the isotopic composition of water column nitrate.

\subsection{Particulate nitrogen}

The relatively short sampling period complicates the assessment of seasonality beyond interannual variabilities, especially given the extraordinary spring flood in 2006. However, it is obvious that the concentration of particulate matter is rather uniform around $30 \pm 10 \mu \mathrm{M}$ throughout most of the 


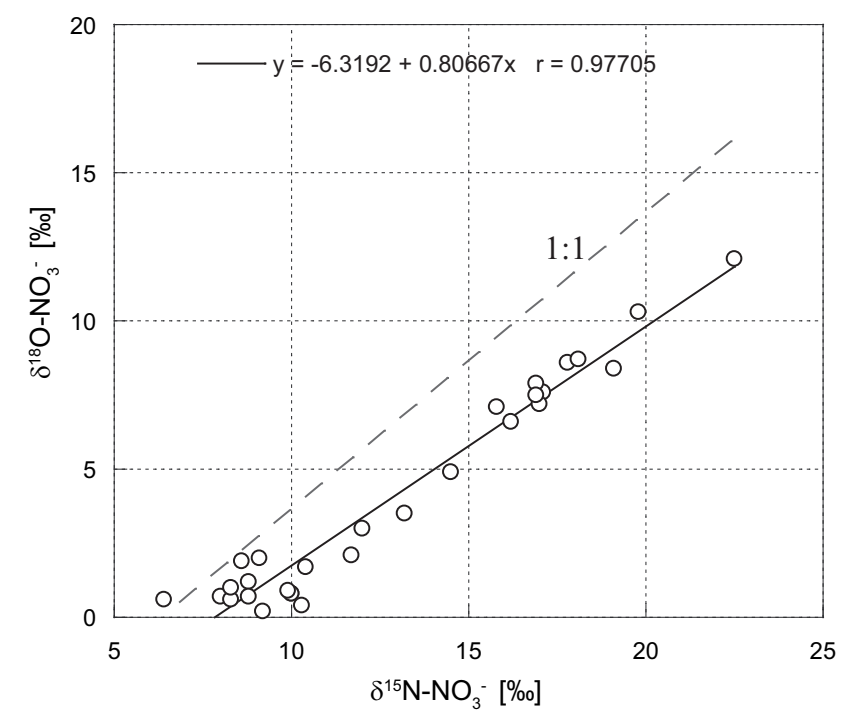

Fig. 3. Relationship between $\delta^{15} \mathrm{~N}-\mathrm{NO}_{3}^{-}$and $\delta^{18} \mathrm{O}-\mathrm{NO}_{3}^{-}$to examine the fractionation factor ratio $\varepsilon^{15} / \varepsilon^{18}$, dashed line represents a $1: 1$ ratio.

year (Table 2), but peaks in early to late summer, with concentrations of 77 to $126 \mu \mathrm{M}$ (Table 2, Fig. 4).

The dominant features are (a) a parallel progression of the annual trends for $\delta^{15} \mathrm{DON}+\mathrm{NH}_{4}^{+}$and $\delta^{15} \mathrm{PN}$ (Fig. 5) and (b) a correlation of PN dynamics with nitrate isotopes and concentration in the river (Fig. 2a, c): the high mean PN concentrations in spring and summer $(65.6 \mu \mathrm{M}$ and $55.0 \mu \mathrm{M}$, compared to 41.4 and 19.6 in autumn and winter, respectively Table 2) are accompanied by low $\delta^{15} \mathrm{PN}$ values $(7.5 \%$ in spring, $7.2 \%$ in summer) and, inversely correlated, low DIN concentration and high nitrate isotope values (cf. Fig. 2a, c). This pattern is most likely due to primary production feeding on inorganic nitrogen in active vegetation periods: such assimilation leads to an increase in the remaining nitrate pool as concentrations decrease. We note that the offset in isotope values of PN and nitrate is higher than the 5\%o usually associated with nitrate assimilation by phytoplankton (Granger, 2004), so that the PN is relatively light in comparison to the DIN pool. Regardless of this finding, nitrate isotope analyses point towards phytoplankton assimilation as a key mechanism (cf. Sect. 4.1). Moreover, supporting the role of phytoplankton, PN concentration peaks in spring (Fig. 2c), with concentrations of $80 \mu \mathrm{M}$ and higher. These peaks coincide with a breakup of the otherwise strong correlation $\left(r^{2}=0.71\right.$, Fig. 6) of PN concentration with $\delta^{15} \mathrm{PN}$ (Fig. 6). This points to massive build-up of particulate matter during a phytoplankton bloom.

Furthermore, the similar curve progression of $\delta^{15} \mathrm{PN}$ and $\delta^{15} \mathrm{DON}+\mathrm{NH}_{4}^{+}$indicates a relationship between the dissolved and the particulate matter fraction (Fig. 4), mirrored in the correlation coefficient of $r^{2}=0.53(\alpha \leq 0.01$, Fig. 5). The lower $\delta{ }^{15} \mathrm{DON}+\mathrm{NH}_{4}^{+}$compared to $\delta{ }^{15} \mathrm{PN}$ suggest that

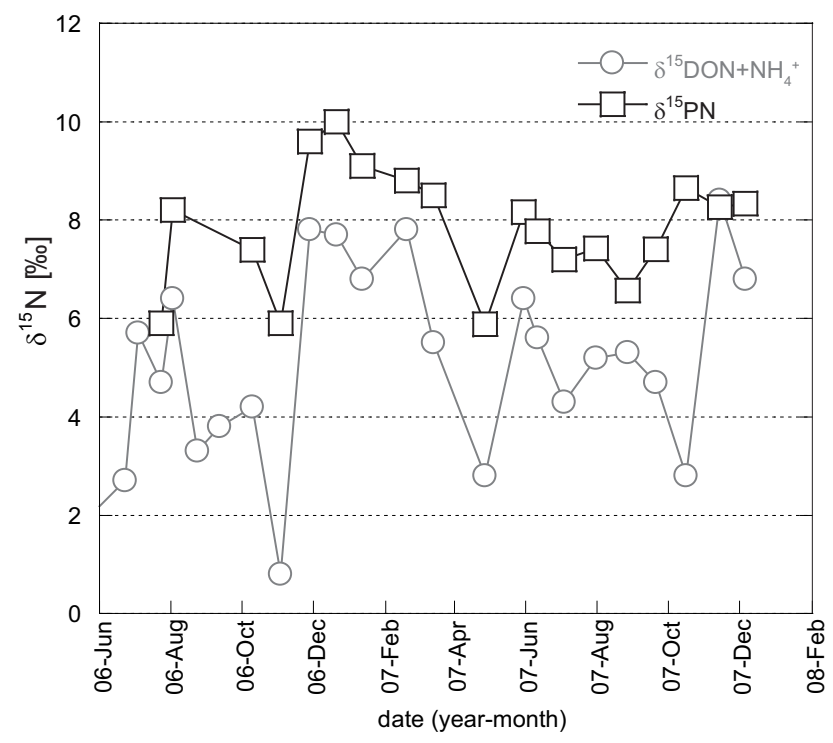

Fig. 4. $\delta^{15} \mathrm{DON}+\mathrm{NH}_{4}^{+}$and $\delta^{15} \mathrm{PN}$ in the Elbe River at the weir of Geesthacht, June 2006-December 2007.

particulate matter is, at any time of year, a significant source of DON and/or ammonium: Phytoplankton cells are known to release DON, especially in their exponential growth phase (Wetz and Wheeler, 2007; Suratman et al., 2008), and remineralisation of particulate matter throughout the year is another possible source of $\mathrm{DON}+\mathrm{NH}_{4}^{+}$.

One peculiar feature in the $\delta^{15} \mathrm{PN}$ progression over the course of the sampling period is a sharp decrease in isotope values just before the increase in PN concentration (Fig. 2c). Assimilation of low- $\delta^{15} \mathrm{~N}$ ammonium at the onset of the bloom in spring could be the reason for this decreasing $\delta{ }^{15} \mathrm{PN}$, since ammonium is the preferred $\mathrm{N}$ source when abundant (Hadas et al., 2009). Later during the year, ammonium is rarely above the detection limit, and is thus obviously rapidly exhausted, leading to subsequent assimilation of DON and nitrate with a higher $\delta^{15} \mathrm{~N}$ value. This results in a $\delta^{15} \mathrm{PN}$ increase over the course of the bloom (April to August, Fig. 2c).

In winter, the PN concentration decreases, while $\delta^{15} \mathrm{PN}$ increases to values near those of nitrate (Fig. 2c). Most likely, this is due to breakdown of living cells in winter, and increased sediment resuspension due to increased flow rates. This suspended matter can be degraded in the sediments and have low $\mathrm{N}$ content, but high $\delta^{15} \mathrm{PN}$ values around 8-10\%owhich is in accordance with $\delta^{15} \mathrm{~N}$ values measured in surface sediments in the Elbe estuary (Serna et al., 2010).

\section{3 $\mathrm{DON}+\mathrm{NH}_{4}^{+}$}

Like nitrate in the river water, the $\mathrm{DON}+\mathrm{NH}_{4}^{+}$load of the Elbe River at the weir of Geesthacht is fed by both external and internal sources: the abiotic external sources of 


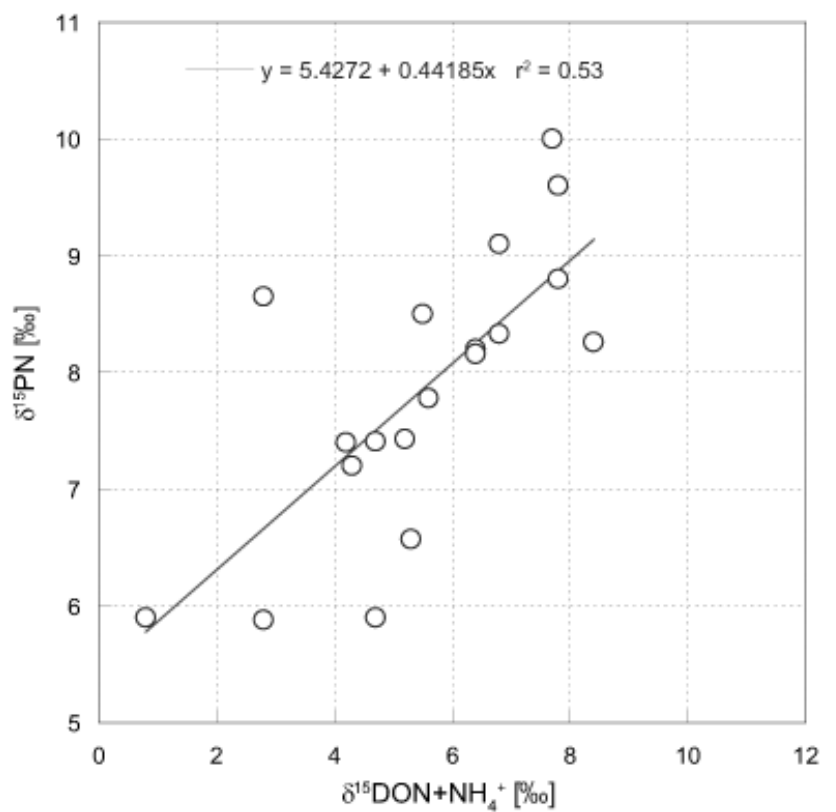

Fig. 5. Relationship between $\delta^{15} \mathrm{DON}+\mathrm{NH}_{4}^{+}$and $\delta^{15} \mathrm{PN}$ in the Elbe River at the weir of Geesthacht, June 2006-December 2007.

$\mathrm{DON}+\mathrm{NH}_{4}^{+}$include terrestrial runoff, such as DON and/or ammonium input by surface runoff, tributaries, groundwater (Valiela et al., 1990; Tobias et al., 2001) and the atmosphere (Cornell et al., 1995). These external sources are often dominated by discharge of sewage treatment plants, and elution of slurry and liquid manure from farmland. Internal cycling includes mineralization and uptake and/or release of DON by phytoplankton (Bronk, 1999; Wetz et al., 2008), and abiotic processes like sorption to particles (Cauwet, 2002).

During our observation period, we found seasonal differences in DON $+\mathrm{NH}_{4}^{+}$concentration and $\delta^{15} \mathrm{DON}+\mathrm{NH}_{4}^{+}$ (Fig. 2b). In contrast to nitrate dynamics, the annual $\mathrm{DON}+\mathrm{NH}_{4}^{+}$cycle appears to be more differentiated and can be separated into four seasonal phases: a distinct peak of isotope values and concentration in winter, followed by a parallel decrease (spring), a secondary maximum in summer, and then slightly decreasing $\mathrm{DON}+\mathrm{NH}_{4}^{+}$concentration and isotope values in autumn before the winter peak. At any time of year, DON isotopes are correlated to PN isotopes (Fig. 5), but the responsible mechanisms are apparently different ones over the course of the year and reflect changes in biological processing and PN composition over an annual cycle, as we describe in detail below.

\subsubsection{Spring}

After a peak in late winter, $\mathrm{DON}+\mathrm{NH}_{4}^{+}$concentration decreases, along with a significant decrease in $\delta^{15} \mathrm{DON}+\mathrm{NH}_{4}^{+}$. In 2006, the signal is a bit more noisy due to the high spring flood, but still recognizable (Fig. 2b). A parallel decrease $\delta^{15} \mathrm{DON}+\mathrm{NH}_{4}^{+}$and $\mathrm{DON}+\mathrm{NH}_{4}^{+}$concentration is

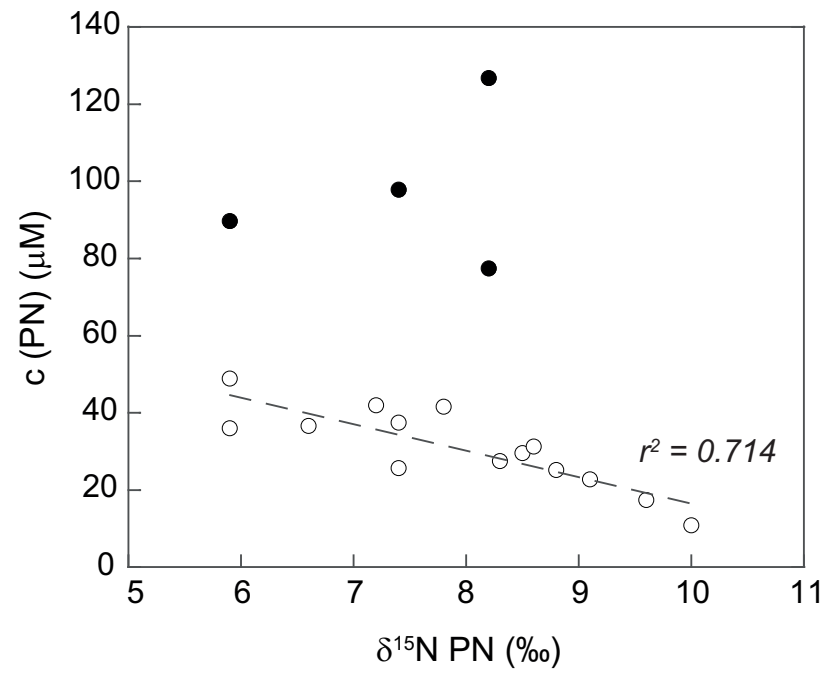

Fig. 6. Correlation of concentration and nitrogen isotope values of particulate matter in the Elbe River. Filled circles are not included in the regression, see text, Sect. 4.2, for details.

somewhat surprising, but an explanation might be the heterogeneous composition of this pool. Only parts of the heterogeneous DON pool in river water are bioavailable (Bronk et al., 2007; Seitzinger and Sanders, 1997; Seitzinger et al., 2002), and can be degraded by indigenous bacteria and/or free dissolved enzymes (Berman et al., 1999). In a study on fifty rivers draining a major part of the Baltic Sea watershed, Stepanauskas et al. (2002) found that the labile fraction of DON was composed of urea and dissolved combined amino acids (DCAA) with $4-20 \%$ of DON each, and $<3 \%$ dissolved free amino acids (DFAA).

The proportion of this bioavailable DON varies by source and land use pattern in the catchment: up to $59 \%$ of DON from urban/suburban stormwater runoff and $30 \%$ from agriculture sources can be bioavailable (Seitzinger et al., 2002). This relatively high biavailable portion may also apply to the industrialized Elbe catchment.

Furthermore, Seitzinger et al. (2002) observed highest uptake rates of DON originating from urban/suburban stormwater runoffs and agriculture sources in spring times, so we hypothesize that this process is important in spring in the Elbe River, too: the decreasing $\delta^{15} \mathrm{DON}+\mathrm{NH}_{4}^{+}$values observed in spring apparently reflect that uptake of the bioavailable fraction is complete to the point that we have no apparent isotope effect, and the low $\delta^{15} \mathrm{DON}+\mathrm{NH}_{4}^{+}$value measured in the remaining pool is probably due to recalcitrant DON that remains in the water column.

\subsubsection{Summer}

In the second distinct phase in $\mathrm{DON}+\mathrm{NH}_{4}^{+}$seasonal cycling (June to August) both concentration and $\delta^{15} \mathrm{DON}+\mathrm{NH}_{4}^{+}$ show a secondary peak, alongside with an increase in PN 
Table 5. Selected nutrient concentrations in the Elbe River at the weir of Geesthacht in the years 2005-2007, measured by the ARGE-Elbe (ARGE 2005, 2007a, b) (d.1. = detection limit , 2.8 $\mu \mathrm{M}$, $0.3 \mu \mathrm{M}$ and $0.7 \mu \mathrm{M}$ for ammonium, phosphate and nitrite, respectively.

\begin{tabular}{clccc}
\hline year & month & $\begin{array}{c}\text { ammonium } \\
{[\mu \mathrm{M}]}\end{array}$ & $\begin{array}{c}\text { o-phosphate } \\
{[\mu \mathrm{M}]}\end{array}$ & $\begin{array}{c}\text { nitrite } \\
{[\mu \mathrm{M}]}\end{array}$ \\
\hline \multirow{6}{*}{2005} & Feb & 10.7 & 1.9 & 1.4 \\
& May & $<$ d.1. & $<$ d.1. & $<$ d.1. \\
& Jun & $<$ d.1. & $<$ d.1. & 1.4 \\
& Jul & $<$ d.1. & 0.6 & $<$ d.1. \\
& Aug & $<$ d.1. & $<$ d.1. & 0.7 \\
& Nov & $<$ d.1. & 2.3 & $<$ d.1. \\
\hline \multirow{6}{*}{2006} & Feb & 33.6 & 1.6 & 1.4 \\
& May & $<$ d.1. & 0.6 & 0.7 \\
& Jun & $<$ d.1. & 0.3 & 0.7 \\
& Aug & $<$ d.1. & 0.6 & $<$ d.1. \\
& Nov & 2.9 & 1.6 & $<$ d.1. \\
& Feb & 2.9 & 1.9 & $<$ d.1. \\
\hline \multirow{4}{*}{2007} & Jun & 4 d.1. & $<$ d.1. & 0.7 \\
& Jul & $<$ d.1. & $<$ d.1. & 1.4 \\
& Aug & 2.9 & $<$ d.1. & 0.7 \\
& Nov & 4.3 & 2.9 & 0.7 \\
\hline
\end{tabular}

concentration (see Sect. 4.2 and Fig. 2b, c). In July 2005 Deutsch et al. (2009) measured low $\delta^{15} \mathrm{~N}-\mathrm{NH}_{4}^{+}$values of 2-3\% in the Elbe River, so we assume that ammonium, even though above the detection limit at this time of year (Table 5), is not responsible for this increase, which should mainly be due to increasing $\delta^{15} \mathrm{DON}$.

Release of DON from PN can occur throughout the year, as is reflected in the close correlation between PN and DON isotopes (Fig. 5), but algae certainly play an important role in the growing season, exudating part of the ingested nutrients in form of dissolved organic matter (Larsson and Hagström, 1979; Collos et al., 1992). We interpret our data from summer, when concentration and $\delta^{15} \mathrm{DON}+\mathrm{NH}_{4}^{+}$peak, as a reflection of a dynamic equilibrium of uptake and release of DON. The release of DON by isotopically heavier phytoplankton causes an increase in both concentration and isotope values of $\mathrm{DON}+\mathrm{NH}_{4}^{+}$. This is supported by the close correlation of $\delta^{15} \mathrm{DON}+\mathrm{NH}_{4}^{+}$and $\delta^{15} \mathrm{PN}$ (Fig. 5), which suggests that ${ }^{15} \mathrm{~N}$ depleted DON is released from particulate N. Phytoplankton, which is highly abundant at this time of year, is a likely source of this DON. This has also been observed in Lake Kinneret, Israel, where Hadas et al. (2009) found a similar relation between particulate organic matter (POM) and $\mathrm{DON}$, and conclude that algal production is a major source for DON.

\subsubsection{Autumn and winter}

In autumn, from September to October, $\mathrm{DON}+\mathrm{NH}_{4}^{+}$concentration and $\delta^{15} \mathrm{DON}+\mathrm{NH}_{4}^{+}$decrease again, followed by parallel increases in winter months to higher values in both concentration and $\delta^{15} \mathrm{DON}+\mathrm{NH}_{4}^{+}$than in summer.

In autumn, at the end of the biological production period, the $\mathrm{DON}+\mathrm{NH}_{4}^{+}$concentration is decreasing, probably due to sinking algal DON production. The remaining DON is isotopically depleted, with isotope values again approaching those found in spring. It is possible that this again is caused by the signal of the remaining recalcitrant fraction, as we hypothesized for the pre-bloom situation in spring. The parallel decrease in concentration may be due to dilution by higher discharge at this time of year. Another possibility for the decrease in isotope and concentration values is interaction with suspended sediments: DON can be adsorbed to sinking particles and thus be removed from the dissolved phase (Cauwet, 2002). Generally, sediments can be a major sink of DON: in the Colne River (which has a TDN composition comparable to the Elbe River), Agedah et al. (2009) observed a similar decrease when ${ }^{15} \mathrm{~N}$-enriched DON is removed from the water column, but we cannot separate this influence from the decrease that can be caused by ceasing productivity in the water column.

The following increase of DON $+\mathrm{NH}_{4}^{+}$concentration and $\delta^{15} \mathrm{DON}+\mathrm{NH}_{4}^{+}$in winter is likely due to the elution of organic fertilisers and remineralisation of terrestrial $\mathrm{PN}$ in the second main fertilisation period in autumn after the last harvest in October before the blocking period for manure application starts (from mid-November to mid-January, DüV, 2009). The use of organic fertilizers is wide-spread in the Elbe catchment (FGG-Elbe, 2009), and high discharge during this time can lead to a significant elution of these substances from the adjacent agricultural areas. Recent measurements of $\delta^{15} \mathrm{~N}-\mathrm{NH}_{4}^{+}$in January 2010 showed low values of $0-1 \%$ at concentrations of $\sim 13 \mu \mathrm{M}$ (Schlarbaum et al., unpublished data), so DON must be highly enriched in ${ }^{15} \mathrm{~N}$ to obtain measured $\delta^{15} \mathrm{DON}+\mathrm{NH}_{4}^{+}$values. Additionally, this elevated concentration in comparison to summer is thus also due to high ammonium concentrations in winter $(10-30 \mu \mathrm{M}$, Table 5), before the onset of primary production or nitrification later during the year.

\section{Summary and conclusions}

In our study addressing inorganic and organic nitrogen in the Elbe River at the weir of Geesthacht, we measured both concentration and stable isotope signatures of nitrate, combined $\mathrm{DON}+\mathrm{NH}_{4}^{+}$and $\mathrm{PN}$. On an annual basis, nearly $23 \%$ of $\mathrm{TDN}$ is in the form of DON $+\mathrm{NH}_{4}^{+}$.

For nitrate the seasonal pattern has two periods with a contrasting development of concentration and dual nitrate isotopes, due to biological processes. We attribute this to nitrate 
assimilation during biological activity, as is supported by the co-variance of $\delta^{15} \mathrm{~N}-\mathrm{NO}_{3}^{-}$and $\delta^{18} \mathrm{O}-\mathrm{NO}_{3}^{-}$.

In contrast, the seasonal cycling of combined $\mathrm{DON}+\mathrm{NH}_{4}^{+}$ is more complex and is influenced by many different factors, both biotic and abiotic. $\mathrm{DON}+\mathrm{NH}_{4}^{+}$is apparently closely related to particulate matter, which apparently is a significant source of DON throughout the year, as indicated by the similar, almost parallel progression of $\delta^{15} \mathrm{DON}+\mathrm{NH}_{4}^{+}$ and $\delta^{15} \mathrm{PN}$. The annual $\mathrm{DON}+\mathrm{NH}_{4}^{+}$cycle can be separated into four periods, with two peaks of both concentration and $\delta^{15} \mathrm{DON}+\mathrm{NH}_{4}^{+}$in summer and winter, and a lower values of both in spring and autumn. We assume that the elution or mineralization of ${ }^{15} \mathrm{~N}$-enriched organic fertiliser, after the harvest in autumn, has an important influence on DON in the Elbe River. In summer, the DON dynamics are governed by biological processing due to DON release by phytoplankton. The decrease in spring and autumn is on the one hand due to autotrophic and heterotrophic uptake (springtime) and on the other hand due to lower biological production in autumn. Our measurements suggest that the recalcitrant DON fraction in the Elbe River is isotopically depleted in ${ }^{15} \mathrm{~N}$, compared to the reactive DON.

Acknowledgements. The authors would like to thank Gerd Blöcker for technical advise and assistance and Tanja Pieplow for help with the nutrient measurements. Two anonymous reviewers are acknowledged for helpful comments that greatly improved the manuscript.

Edited by: S. Bouillon

\section{References}

Agedah, E. C., Binalaiyifa, H. E., Ball, A. S., and Nedwell, D. B.: Sources, turnover and bioavailability of dissolved organic nitrogen (DON) in the Colne estuary, UK, Mar. Ecol.-Prog. Ser., 382, 23-33, 2009.

ARGE: Wassergütedaten der Elbe - Zahlentafel 2004, Arbeitsgemeinschaft für die Reinhaltung der Elbe, Hamburg, 2005.

ARGE: Wassergütedaten der Elbe - Zahlentafel 2005, Arbeitsgemeinschaft für die Reinhaltung der Elbe, Hamburg, 2007a.

ARGE: Wassergütedaten der Elbe - Zahlentafel 2006, Arbeitsgemeinschaft für die Reinhaltung der Elbe, Hamburg, 2007b.

ARGE: Gewässergütebericht der Elbe 2006, Arbeitsgemeinschaft für die Reinhaltung der Elbe, Hamburg, 2008.

Behrendt, H., Bach, M., Opitz, D., and Pagenkopf, W. G.: Maßgebliche anthropogene Einflüsse auf die Gewässerqualität, in: Wasser- und Nährstoffhaushalt im Elbegebiet und Möglichkeiten zur Stoffeintragsminderung, edited by: Becker, A. and Lahmer, W., Weissensee Verlag, Berlin, 42-58, 2004.

Berman, T., Béchemin, C., and Maestrini, S. Y.: Release of ammonium and urea from dissolved organic nitrogen in aquatic ecosystems, Aquat. Microb. Ecol., 16, 295-302, 1999.

Böhlke, J. K., Mroczkowski, S. J., and Coplen, T. B.: Oxygen isotopes in nitrate: new reference materials for ${ }^{18} \mathrm{O}:{ }^{17} \mathrm{O}:{ }^{16} \mathrm{O}$ measurements and observations on nitrate-water equilibration, Rapid Commun. Mass Sp., 17, 1835-1846, 2003.
Böttcher, J., Strebel, O., Voerkerlius, S., and Schmidt, H. L.: Using isotope fractionation of nitrate nitrogen and nitrate oxygen for evaluation of microbial denitrification in a sandy aquifer, $\mathrm{J}$. Hydrol., 114, 413-424, 1990.

Brandes, J. A. and Devol, A. H.: A global marine-fixed nitrogen isotopic budget: Implications for Holocene nitrogen cycling, Global Biogeochem. Cy., 16, 1120, doi:10.1029/2001gb001856, 2002.

Brockmann, U. H. and Pfeiffer, A.: Seasonal changes of dissolved and particulate material in the turbidity zone of the River Elbe, in: Estuarine Water Quality Management, edited by: Michaelis, W., Springer, Heidelberg, 327-334, 1990.

Bronk, D. A.: Rates of $\mathrm{NH}_{4}^{+}$uptake, intracellular transformation and dissolved organic nitrogen release in two clones of marine Synechococcus spp., J. Plankton Res., 21, 1337-1353, 1999.

Bronk, D. A.: Dynamics of DON, in: Biogeochemistry of Marine Dissolved Organic Matter, edited by: Hansell, D. A. and Carlson, C. A., Academic Press, New York, 153-247, 2002.

Bronk, D. A., See, J. H., Bradley, P., and Killberg, L.: DON as a source of bioavailable nitrogen for phytoplankton, Biogeosciences, 4, 283-296, doi:10.5194/bg-4-283-2007, 2007.

Casciotti, K. L., Sigman, D. M., Hastings, M. G., Bohlke, J. K. and Hilkert, A.: Measurement of the oxygen isotopic composition of nitrate in seawater and freshwater using the denitrifier method, Anal. Chem., 74, 4905-4912, 2002.

Cauwet, G.: DOM in the coastal zone, edited by: Hansell, D. A., and Carlson, C. A., Academic Press, New York, 579-609, 2002.

Collos, Y., Dohler, G., and Biermann, I.: Production of dissolved organic nitrogen during uptake of nitrate by Synedra planctonica: implications for estimates of new production in the oceans, J. Plankton Res., 114, 1025-1029, 1992

Cornell, S., Rendell, A., and Jickells, T.: Atmospheric inputs of dissolved organic nitrogen to the oceans, Nature, 376, 243-246, 1995.

Dähnke, K., Bahlmann, E., and Emeis, K.-C.: A nitrate sink in estuaries? An assessment by means of stable nitrate isotopes in the Elbe estuary, Limnol. Oceanogr., 53, 1504-1511, 2008.

Deutsch, B., Voss, M., and Fischer, H.: Nitrogen transformation processes in the Elbe River: Distinguishing between assimilation and denitrification by means of stable isotope ratios in nitrate, Aquat. Sci., 71, 228-237, 2009.

Düngeverordnung (DüV) in der Fassung der Bekanntmachung vom 27 Februar 2007 (BGB1. I S. 22), geändert durch Artikel 1 der Verordnung vom 6 Februar 2009 (BGB1. I S. 153), 2009.

FGG-Elbe: Umweltbericht zum Entwurf des Maßnahmenprogramms gemäß Art. 11 der WRRL für die Flussgebietsgemeinschaft Elbe (FGG Elbe), Hannover, 2009.

Granger, J., Sigman, D. M., Needoba, J. A., and Harrison, P. J.: Coupled nitrogen and oxygen isotope fractionation of nitrate during assimilation by cultures of marine phytoplankton, Limnol. Oceanogr., 49, 1763-1773, 2004.

Grasshoff, K., Ehrhardt, M., and Kremling, K. (Eds.): Methods of Seawater Analysis, 3rd edition, Verlag Chemie, Weinheim, 1999.

Hadas, O., Altabet, M. A., and Agnihotri, R.: Seasonally varying nitrogen isotope biogeochemistry of prticulate organic matter in Lake Kinneret, Israel, Limnol. Oceanogr., 54, 75-85, 2009.

Hebbel, H. and Steuer, D.: Empirische Untersuchungen zur Berechnung von Frachten in Fließgewässern, in: Discussion Papers in Statistics and Quantitative Economics, edited by: Hauptmann, H. and Krumbholz, W., Hamburg, 2006. 
Howarth, R. W.: Human acceleration of the nitrogen cycle: drivers, consequences, and steps toward solutions, Water Sci. Technol., 49, 7-13, 2004.

Johannsen, A., Dähnke, K., and Emeis, K.: Isotopic composition of nitrate in five German rivers discharging into the North Sea, Org. Geochem., 39, 1678-1689, doi:10.1016/j.orggeochem.2008.03.004, 2008.

Kendall, C.: Tracing nitrogen sources and cycling in catchments, in: Isotope Tracers in Catchment Hydrology, edited by: Kendall, C. and McDonnell, J. J., Elsevier, 521-576, 1998.

Knapp, A. N., Sigman, D., and Lipschultz, F.: N-isotopic composition of dissolved organic nitrogen and nitrate at the Bermuda Atlantic Time-Series study site, Global Biogeochem. Cy., 19, GB1018, doi:10.1029/2004GB002320, 2005.

Koroleff, F.: Total and organic nitrogen, in: Methods of Seawater Analysis, edited by: Grasshoff, K., Ehrhard, M., and Kremling, K., Verlag Chemie, Weinheim, 125-139, 1976.

Ladwig, N.: Kritische Betrachtung von Eutrophierungstendenzen in der inneren Deutschen Bucht, PhD thesis, Christian-AlbrechtsUniversity, Kiel, 2010.

Larsson, U. and Hagström, Å.: Phytoplankton exudate release as an energy source for the growth of pelagic bacteria, Mar. Biol., 52, 199-206, 1979.

Lehmann, M. F., Sigman, D. M., and Berelson, W. M.: The effect of benthic nitrogen cycling on the delta N-15 and delta O-18 of water-column nitrate. Geochim. Cosmochim. Ac., 67, p. A249, 2003.

Meybeck, M.: C, N, P and S in rivers: From sources to global inputs, in: Interactions of $\mathrm{C}, \mathrm{N}, \mathrm{P}$, and S Biogeochemical Cycles and Global Change, edited by: Wollast, R., Mackenzie, F. T., and Chou, L., Springer Verlag, Berlin, 163-193, 1993.

OSPAR: Second OSPAR Integrated Report on the Eutrophication Status of the OSPAR Maritime Area, OSPAR Commission, 2008.

Schlarbaum, T., Dähnke, K., and Emeis, K.: Dissolved organic nitrogen turnover in the Elbe estuary/NW Europe: results of nitrogen isotope investigations, Mar. Chem., 119, 91-107, doi:10.1016/j.marchem.2009.12.007, 2010.

Seitzinger, S. P. and Sanders, R. W.: Contributions of dissolved organic nitrogen from rivers to estuarine eutrophication, Mar. Ecol.-Prog. Ser., 159, 1-12, 1997.

Seitzinger, S. P., Sanders, R. W., and Styles, R.: Bioavailability of DON from natural and anthropogenic sources to estuarine plankton, Limnol. Oceanogr., 47, 353-366, 2002.

Serna, A., Patsch, J., Dähnke, K., Wiesner, M. G., Hass, H. C., Zeiler, M., Hebbeln, D., and Emeis, K. C.: History of anthropogenic nitrogen input to the German Bight/SE North Sea as reflected by nitrogen isotopes in surface sediments, sediment cores and hindcast models, Cont. Shelf Res., 30, 1626-1638, 2010.
Sigman, D. N., Casciotti, K. L., Andreani, M., Barford, C., Galanter, M., and Böhlke, J. K.: A bacterial method for the nitrogen isotopic analysis of nitrate in seawater and freshwater, Anal. Chem., 73, 4145-4153, 2001.

Solórzano, L. and Sharp, J. H.: Determination of total dissolved nitrogen in natural waters, Limnol. Oceanogr., 25, 751-754, 1980.

Stanley, E. H. and Maxted, J. T.: Changes in the dissolved nitrogen pool across land cover gradients in Wisconsin streams, Ecol. Appl., 18, 1579-1590, 2008.

Stepanauskas, R., Edling, H., and Tranvik, L. J.: Differential dissolved organic nitrogen availability and bacterial aminopeptidase activity in limnic and marine waters, Microb. Ecol., 38, 264-272, 1999a.

Stepanauskas, R. Leonardson, L., and Tranvik, T. J.: Bioavailabilty of wetland-derived DON to freshwater and marine bacterioplankton, Limnol. Oceanogr., 44, 1477-1485, 1999 b.

Stepanauskas, R., Jørgensen, N. O. G., Eigaard, O. R., Žvikas, A., Tranvik, L. J., and Leonardsen, L.: Summer inputs of riverine nutrients to the Baltic Sea: bioavailability \& eutrophication relevance, Ecol. Monogr., 72, 579-597, 2002.

Suratman, S., Weston, K., Jickells, T., Chance, R., and Bell, T.: Dissolved organic matter release by an axenic culture of Emiliania huxleyi, J. Mar. Biol. Assoc. UK, 88, 1343-1346, 2008.

Tobias, C. R., Harvey, J. W., and Anderson, I. C.: Quantifying groundwater discharge through fringing wetlands to estuaries: Seasonal variability, methods comparison, and implications for wetland-estuary exchange, Limnol. Oceanogr., 46, 604-615, 2001.

Valiela, I., Costa, J., Foreman, K., Teal, J. M., Howes, B., and Aubrey, D.: Transport of groundwater-borne nutrients from watersheds and their effects on coastal waters, Biogeochemistry, 10, 177-197, 1990.

Wetz, M. S. and Wheeler, P. A.: Release of dissolved organic matter by coastal diatoms, Limnol. Oceanogr., 52, 798-807, 2007

Wetz, M. S., Hales, B., and Wheeler, P. A.: Degradation of phytoplankton-derived organic matter: Implications for carbon and nitrogen biogeochemistry in coastal ecosystems, Estuar. Coast. Shelf S., 77, 422-432, 2008.

Wiegner, T. N., Seitzinger, S. P., Glibert, P. M., and Bronk, D. A.: Bioavailability of dissolved organic nitrogen and carbon from nine rivers in the eastern United States, Aquat. Microb. Ecol., 53, 277-287, 2006.

Williams, P. M. and Druffel, E. R. M.: Radiocarbon in dissolved organic matter in the central North Pacific Ocean, Nature, 330, 246-248, 1987. 